DOI: doi.org/10.21009/IJLECR.071.04

Received: 19 June 2021

Revised: 22 June 2021

Accepted: 25 June 2021

Published: 30 June 2021

\title{
CRITICIZING THE TRANSLATION OF GIBRAN'S “THE BROKEN WINGS": EXTRA AND INTRA-TEXTUAL ANALYSIS
}

\author{
Ati Sumiati $^{1, \mathrm{a})}$, Romel Noverino ${ }^{2, \mathrm{~b})}$ \\ Graduate School of Universitas Negeri JakartaJakarta, Indonesia ${ }^{1)}$, \\ Graduate School of Gunadarma University, Jakarta, Indonesia ${ }^{2)}$ \\ atisumiati@unj.ac.id ${ }^{\text {a) }}$,romel@staff.gunadarma.ac.id ${ }^{\text {b) }}$
}

\begin{abstract}
This research was based on the fact that in the discipline of Translation Studies, Translation Criticism (TC) is highly underrated. Not many research that discuss about the issue due to the fact that doing $\mathrm{TC}$ is not as simple as flickering your fingers. It requires mastery of the theories of translation and mastery of linguistic and socio-cultural aspects from both languages. It was therefore, this study aimed to: (1) identify and elaborate the aspects of doing TC from extratextual and intra-textual aspects; (2) give evaluation on the basis of the quality of the translation. To achieve the aims of the study, Gibran famous novel The Broken Wings (TBW) and its Indonesian translation Sayap-sayap Patah (SSP) are used as the data. Data collecting procedures are identifying the extra-textual and intra-textual aspects from TBW and SSP, highlighting them, and placing them on the table of data collection. The writer then analyzed the data by employing the theory proposed by Nords and Newmark on TC and the Larson for the quality of translation. The findings showed that the analysis of extra-textual focusing on the ST and TT has shown that the intention of Gibran to write TBW is to depict the life during his era during which the era deals with various problems that plagued early-twentieth-century Lebanon and foremost to tell a tale of tragic love, set at the turn of the 20th century in Beirut. It is perhaps most aptly described as a "love-poem-in-prose," unified by the force of its universal theme of love, though critics have regarded it from the traditional perspective of the novella. Based on the analysis of the intratextual aspects, it is shown that TBW contains many figures of speech, to name a few are the similes which dominate, the metaphor and the personification. TBW also contains so many cultural words that refer to ecology to describe the beautiful landscape of the Lebanon, the material culture to describe the flowers, fruits, and also the organization of Lebanese with the "houris". The translator was able to perceive and retain the meaning of each making the translation fulfilled the criteria of good translation, clear, accurate and natural.
\end{abstract}

Keywords: translation criticism, figurative languages, quality of translation, The Broken Wings, Sayap-sayap Patah

Translation is best regarded as a medium to bridge the cultures of various nations which without it communication between and across nations and cultures would be impossible. The translation study has a long history with the so many new emerging concepts and how it interacts with another area of stud, namely literature. The 1950s foresaw the contribution of translation study into other discipline such as sociology, literature, linguistics, psychology, deconstructionism, 
feminism, and even post-colonialism. The ideas and theories from other disciplines and approaches have introduced new perspectives for translation studies. The emerging concept of Translation Criticism (TC) also flourishing during recent years yet unfavoured by so many. This concept allows people to distinguish the bad from the good translation; overall it looks on the overall aspects of translation. Not until recent years that this area in translation study has long been neglected due to the difficulty in achieving appropriate evaluation or we say as criticism.

Many approaches have been discovered to propose theory for TC but none is sufficiently accepted. Tagiyeh (2005) stated that translation criticism can be defined as a comprehensive analysis of a translated work from different aspects, which means that TC must employ aspects of translation comprehensively, the texts, the readers, the purpose, the linguistics aspects and sociocultural aspects which are embedded in translation theory. Translation criticism is a significant sub-field of translation studies, because it improves competence of the translator, expands the knowledge and understanding of the source and target texts by presenting options; it enables us to fully comprehend both texts. (Newmark, 1988). This theory makes it clear that TC is a beneficial tool for translator to upgrade his ability in translation and he must have excellent knowledge and understanding of Source Language (SL) and Target Language (TL). Newmark further considers the translation criticism as a vital link between translation theory and its practice (1988).

At the beginning of its emergence, the critics of translation only focused on the analysis on the problems emerge from the translation and is very biased with the translator own's perspective. They do not have sufficient tools to conduct TC and by far the generalized assumption when reviewing TC is by providing the evaluation as "the translation is poor", "the translation is inaccurate", "the translation is great", etc. those which are deemed really subjective opinion. This is proven wrong since the purpose of TC is not to determine whether a translation is "correct" or "incorrect" or "bad" or "good" rather to analyze what sort of decisions are taken into account during translation process. Then, as the translation study went under development, many approaches emerged one of it is error analysis which then became the embryo of TC. TC is no longer conveying subjectivity rather more to the systematic analysis on the product of translation.

TC is more to the decision on the good or bad on the product of translation but not partially but comprehensively and how the meaning contained in the translation is received by the TL readers, not only on the aspect of language but also the culture. And again this is not to "judge" the end result of translation but to make the quality of the translation improved. The improvement will enable the writer, the translator, and the readers of the text to communicate together, communicating and bridging the language and culture. There is no perfect translation; it must be related with the ideology lies behind it, the ideology of the translators. In every translation, deviation of forms and meanings might be occurred in order to have clear, accurate, and natural translation (Larson, 1984).

Newmark (1988) further elaborates on TC that the biggest challenge for the critics is the ability to identify aspects of translation and principles of translation in the text to be criticized. $\mathrm{He} / \mathrm{she}$ must be able to review, give insight, opinion, in terms of the principles used by the translators. Some points worth considering in doing TC are: 1) the critics must be able to analyze the ST; 2) to understand the intention and attitude of the translator; 3) to compare the TT with TT; 4) and lastly to provide review/evaluation on the translation. These aspects might seem simple yet pertinent in conducting TC.

Study by Kreiner (2006) entitled "Translation criticism and unknown source texts" focuses on translation criticism executed by parties who do not know the source text. Using three Danish translations of the Old English poem of Beowulf, this study discusses whether it is possible to criticize and pass judgment on translations when the source text is not available for consultation. It is shown that, by setting up precise parameters and a procedure for such an analysis, one can indeed 
make tentative comments. Another study was conducted by Tezcan (2015) entitled "The applicability of translation criticism approaches to different text types" This thesis aims at analyzing the applicability of translation criticism approaches discussed under the turns in Translation Studies to different text types. The analysis has been carried out by applying translation criticism approaches of Popovic, Koller, Reiss, House, Van den Broeck, Toury and Berman to different text types respectively. In the light of the examples discussed in Analysis of Samples part, this study has concluded that there is no general translation criticism approach that can be applied to all text types since the approaches have partially been applied for the text types mentioned above. Hewson (2011) also imposed the importance of TC in analyzing translation product, he investigated the $\mathrm{TC}$ in Madame Bovary and Emma, the aim is to understand where the text stands in relation to its original by examining the interpretative potential that results from the translational choices that have been made. The results of the analyses are used to construct a hypothesis about each translation, which is classified according to two scales of measurement, one distinguishing between "just" and "false" interpretations, and the other between "divergent similarity", "relative divergence", "radical divergence" and "adaptation".

Due to its difficulty, this study is conducted to do a TC in Gibran's The Broken Wings and its Indonesian version, Sayap-Sayap Patah. The writer is intrigued to discover the possibility on the emergence of differences on the basis of extra-textual and intra-textual aspects within ST and TT and to evaluate the quality of translation. The aims of this study are to: (1) identify and elaborate the aspects of doing TC from extra-textual and intra-textual aspects; (2) give evaluation on the basis of the quality of the translation.

\section{Literature Review}

\section{On the Concept of Translation}

Many experts have their own definition about translation. Based on Cambridge Advanced Learner's Dictionary, translation is something which is translated, or the process of translating something, from one language to another. It refers to the process of changing the form of source language into target language. According to Larson (1984) in his book Meaning Based on Translation, he stated translation as a change of form from the Source Language (SL) into a Receptor Language (RL) in which the meaning must be held constant. To the definition by Larson, the form of the text is changed, but the meaning of the new form must not change. The only one that should change is only the form of the text, which is changed from SL to TL, not the meaning. Meanwhile, Nida and Taber (1969) stated that translation consists of reproducing in the receptor language the closest natural equivalent of the source language message, first in terms of meaning and second in terms of style. Nida and Taber said that Source Language (SL) and Target Language (TL) should meet the closest equivalence, both in term of meaning and style. Newmark (1988) also stated that translation is rendering the meaning of a text into another language in the way the author intended in text. It means one should translate or change the form of SL to the TL, but should consider the meaning which is intended by the author of SL. The new form must contain the right meaning of SL.

\section{Translation Criticism (TC)}

Perceiving the definition on the concept of criticism from Oxford Advanced Learner's Dictionary, the word criticism means "the act of expressing disapproval of somebody/something and opinions about their faults or bad qualities; a statement showing disapproval". This leads to framework that criticism is to evaluate and interpret the variety of elements for example, music, arts, film, literature, etc. to gain meaning from cultural perspectives. As stated by Taqiyeh (2005) that Translation criticism (TC) can be defined as looking comprehensively at different aspects of a 
translated work. Though the scope of translation criticism is infinite, but we there are some principles for the work which the author intends to talk about. While Newmark mentioned that TC is more concern with understanding how translated texts work (rather than with traditional concepts of quality) and seek to define the translator's method and purpose. On the same rendition, Hatim and Mason (1990b) suggested that Criticism of translation quality should be grounded on thorough analysis and description. Some critics prefer to eschew value judgments, prefer not to proclaim one translation better than another. These notions of TC have one thing in common that engulfs the importance of conducting TC, comprehensive analysis on various aspects of translation.

When we talk about translation criticism, we can make direct comparison with the critiques that have been done in other field such as literature, books, novels, etc. The discussion on this topic is yet rarely conducted because not so many people are familiar in critiquing translation products. Hence this critic brings benefit to make the result of the translation better. The so many activities of criticism are conducted partially that is only in evaluating the parts of the translation that are not accurate; hence this leads to subjectivity in evaluating the quality of the translation.

The criticism should be taken into account the other aspects of analysis, evaluation, interpretation, and or assessment in translation. The critics should also consider the text type as stated by Reiss (2000) into: informative texts, expressive texts, operative texts and audio-medial texts. A critic should be able to understand the nature of the text types before he/she conducting critique and the linguistics components of the texts such as phonology, morphology, semantics, syntax, and discourse.

Translation criticism is a pertinent activity to be conducted in the final step of translation. Newmark (1988) also emphasized the importance of this criticism: firstly, because it painlessly improves your competence as a translator; secondly, because it expands your knowledge and understanding of your own and the foreign language, as well as perhaps of the topic; thirdly, because, in presenting you with options, it will help you to sort out your ideas about translation. Newmark (1988) proposed five things that have to be included in the TC (1) a brief analysis of the SL text stressing its intention and its functional aspects; (2) the translator's interpretation of the SL text's purpose, his translation method and the translation's likely readership; (3) a selective but representative detailed comparison of the translation with the original; (4) an evaluation of the translation - (a) in the translator's terms, (b) in the critic's terms; (5) where appropriate, an assessment of the likely place of the translation in the target language culture or discipline.

Further on in the study of translation, translation criticism is categorized as applied translation study, Holmes in Munday (2001) divided the translation studies area into the following:

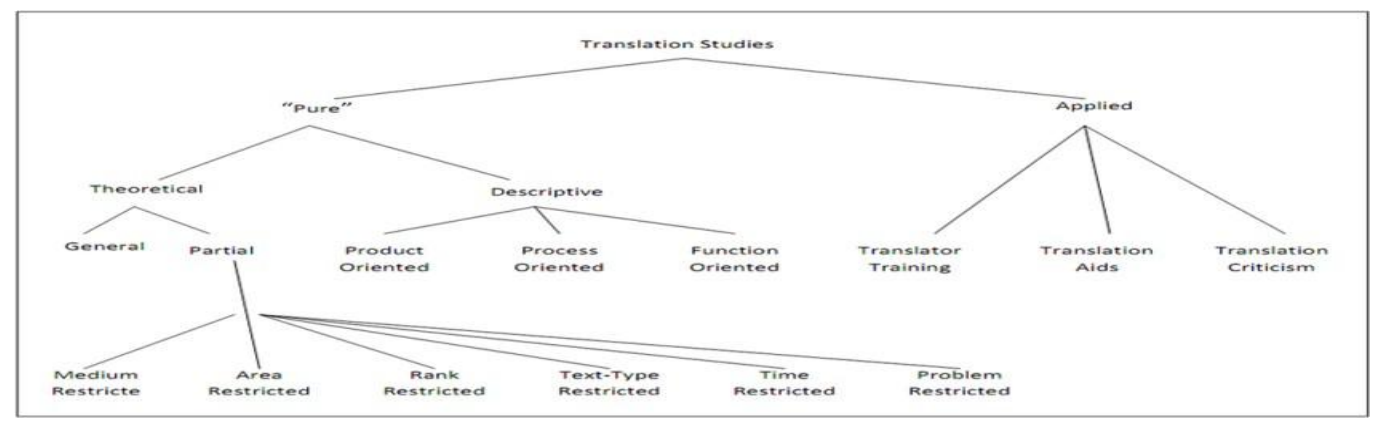

Diagram1. Holmes Area of Translation Study

If we observe from that diagram, Holmes divided the translation study into 2 areas: pure and applied. Pure are again divided into theoretical and descriptive while applied area of translation is divided into translator training, translation aids, and translation criticism. 


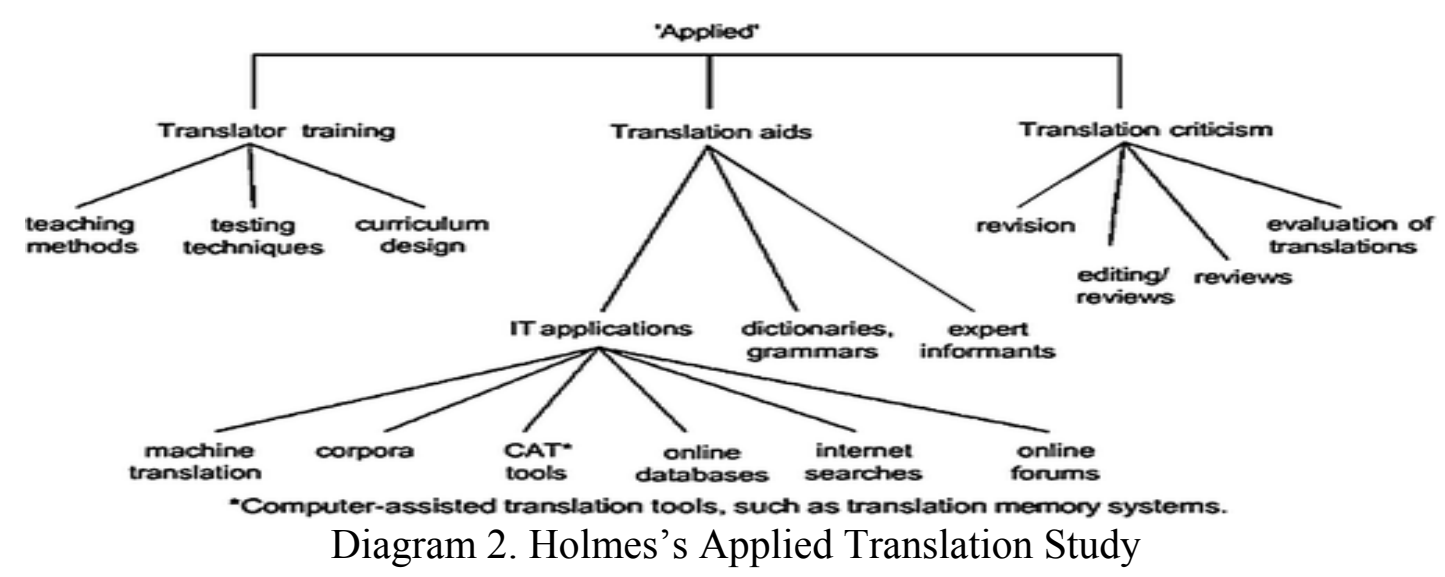

Since this study focuses more on TC it is then categorized as "applied" translation studies. Holmes further elaborated that in TC, four steps of analysis must be carried on: revision, editing, reviews, and evaluation of translations. Revision is perceived as an activity of TC whereby we conduct error analysis by comparing the ST and TT as an effort to revise the TT. Evaluation is a stage where we evaluate the result of a translation while review is the assessment of the published translation.

In conducting TC, text analysis is really pertinent. It is considered as the foundation to be able to conduct TC. By analyzing the texts of ST and TT, the critic can determine what solutions the translators have to offer when they come across problems in translating. The importance of text analysis in conducting TC is posed by Nord (2005), he stated that extra-textual and intra- textual factors are really important. Extra-textual factors are communicative and situational factors that use ST. These factors constitute a text's external structure, and they include the Sender, Sender's intention, audience, medium/channel, place, time, motive, and function (Nord 2005). The intratextual factors are those factors concerned mostly with the internal factors of the translated text including: subject matter, content, and composition of the text, presuppositions, lexis, sentence structure, and even non-verbal elements. These factors are contributing to each other profoundly. This study focuses more on evaluating both factors, extra-textual and intra- textual but merely on the surface basis.

In supporting Nord's opinion on TC, Newmark (1988) also posed several stages in conducting TC: 1) analysis of ST stressing its intention and functional aspects; 2) analysis of the translator's interpretation of the SL text's purpose, his translation method and the translation's likely readership; 3) selective but representative detailed comparison of ST and TT; 4) evaluation of the translation (a) in the translator's terms, (b) in the critic's terms; 5) where appropriate, an assessment of the likely place of the translation in the TL culture or discipline .

\section{Defining the Quality of Translation}

As mentioned previously that in doing TC, one must consider the quality of translation. In this study the instrument used to analyze the quality of translation is based on Larson (1984). She stated that a good translation is a qualified translation in which able to accurately deliver the meaning from Source Language to Target Language. How good or accurate translation work is, it depends on three components; accuracy, clarity, and naturalness. Many experts in translation field have the same opinion on the quality of a good translation. A good translation should meet three requirements as follows 1) a translation should be accurate in a view of the content, the meaning recreated in the target text has to be the same as the source text, 2) a translation should consider the norms and culture inclined to the target language, and 3) a translation should be easily understood 
by target readers (Nababan: 2012). Three parameters to assess those translation qualities presented as accuracy, acceptability, and readability. Accuracy is a term to evaluate translation works to determine equivalency between the source language and target language. Besides that there is acceptability. This term refers to whether presented translation is appropriate in target language norms, values, and cultures, in both micro and macro level. The last one, readability aspect refers to whether a translation text is easy to understand.

\section{METHOD}

This study is a qualitative contrastive analytical method that examines the original novel of The Broken Wings (TBW) written by Kahlil Gibran with its Indonesian translation Sayap- sayap Patah (SSP) by Sabri from Yayasan Bentang Budaya Publisher. The Indonesian translation was published in 1999. The data involved are simple words, phrases and sentences in the original text 'The Broken Wings' and compare them with their Indonesian equivalents in the target text (SayapSayap Patah). Those simple and expression from ST and TT are highlighted to show the differences of meaning on the level of extra-textual and intra-textual. The collecting techniques are by reading both the ST and TT, focusing on the different of meaning that can be evaluated easily. Each sample of data is observed by employing Nords and Newmark criteria for TC and Larson for evaluation for TC. In the analysis stage, the writer compares and contrasts the extra-textual and intra-textual aspects of the ST and TT. The theories of translation also provided to contribute on explaining the result of the translation, whether it delivers the meaning clearly, accurately, and naturally.

\section{RESULTS AND DISCUSSION}

This section analyses and discusses the selected examples of the ST compared to the TT of "The Broken Wings" and "Sayap-sayap Patah". As Nord (2005) stated that the process of TC starts from analyzing text in terms of the extra-textual and intra-textual aspects. By doing this, the writer compares and contrasts both aspects and the final stage is determining the quality of the translation of The Broken Wings whether or not it has met the principle of translation: clear, accurate, and natural (Larson, 1984). This study also examines the occurrence of cultural words and figurative language, which the writer found in TBW.

\section{Extra-textual Analysis of the ST "The Broken Wings" and TT "Sayap-sayap Patah"}

The Broken Wings was written by Kahlil Gibran. As the information retrieved from https://poets.org/poet/kahlil-gibran (accessed July 12, 2020), Kahlil Gibran, known in Arabic as Gibran Khalil Gibran, was born January 6, 1883, in Bsharri, Lebanon, which at the time was part of Syria and part of the Ottoman Empire. He was the youngest son of Khalil Sa'd Jubran, a tax collector eventually imprisoned for embezzlement, and Kamila Jubran, whose father was a clergyman in the Maronite Christian Church. In 1885 Gibran immigrated with his mother and siblings to the United States, where they settled in the large Syrian and Lebanese community in Boston, Massachusetts. It was there that Gibran learned English and enrolled in art classes. His mother supported the family as a seamstress and by peddling linens. The Biblically inspired The Prophet was especially popular in the 1960s. Gibran was active in a New York-based ArabAmerican literary group called the Pen League, whose members promoted writing in Arabic and English. Throughout his life he would publish nine books in Arabic and eight in English, which ruminate on love, longing, and death, and explore religious themes. He died of cirrhosis of the liver on April 10, 1931, in New York City.

As for the translation, TBW was translated by Sabri from Yayasan Bentang Budaya. Cited from its website (retrieved July 12, 2020), https://dapobas.kemdikbud.go.id/home?show=isidata\&id=1457, Yayasan Bentang Budaya is a 
publisher is a publisher that publishes more books related to culture. Because it is a part of culture, many literary books (including literary works) are published by this publisher. In addition to publishing new works, Yayasan Bentang Budaya republished works that had previously been published by other publishers (usually those published by Jakarta publishers), for example Jentera Lepas (1994) by Ashadi Siregar, previously published by Cypress (1979). Not many information can be accessed concerning the translator, Sabri. The SSP was first published in June, 1999. It is undoubtedly expected that the publisher decided to make the translation TBW simply because it is a very famous novel and by that the publisher hoped to gain more income benefit.

The intention of the writer is also pertinent aspect in extra-textual level. The novel was written expressively to convey the writer feeling towards his beloved one, Selma Karamy. They were a two star-crossed lovers. Their love never succeeded and they have to face the brutality of tragic love story. Broken Wings is set between 1898 and 1902, a period Gibran spent in Lebanon, mostly in Beirut, where the action unfolds. At that time, various problems that plagued earlytwentieth-century Lebanon emerged and worsen the condition of social conventions, clerical corruption, and the status of women.

The Broken Wings was written for readers in adult age, both men and women. This novel brings about a very sensitive theme as such the issue of family feud, class stratification, religion, and also social prejudices against women. Therefore, the readers are required to posses adequate knowledge to really plunging and comprehending themselves.

This novel is presented in 11 short stories starts from "Foreword", "Silent Sorrow", "The Hand of Destiny", "Entrance to the Shrine", "The White Torch", "The Tempest", " The Lake of Fire", "Before the Throne of Death", "Between Christ and Ishtar", "The Sacrifice", and "The Rescuer". In each short story, the writer (perhaps Kahlil Gibran himself) as the main character and his lover, Selma always appear.

\section{Intratextual Analysis of the TT "Sayap-Sayap Patah (SSP)"}

This analysis focuses on identifying the aspects contained in the TT of SSP including the language being used, the content, presupposition, text composition, nonverbal aspect, lexemes, sentence structure, and supra segmental features of TT. This study focuses more on explaining the content and delivery of meaning between ST and TT.

The content of The Broken Wings is gathered from the site https://www.enotes.com/topics/broken-wings (retrieved July 12, 2020), "The Broken Wings" is considered Gibran's best writing in Arabic. The prose poem, set in Lebanon, is written in the first person and skillfully uses everyday words. Gibran effectively engages the reader in the work's depiction of emotion, alienation, and the longing for connections. The central male character is a young Lebanese student who meets Ferris Effandi, a friend of his father. The young man meets and falls in love with Effandi's daughter, Selma, who is described as "beautiful in both spirit and body." They are prevented from marrying when the village bishop chooses Selma to be the wife for his nephew. After Selma marries, she and her friend do not meet again until they see each other at Effandi's house just before his death. When Selma reveals the conditions of her unhappy marriage, Effandi asks the young man to be Selma's brother and friend. Defying the social customs of the day, the two meet secretly and regularly in a secluded temple to talk and share their thoughts. These bittersweet hours spent together cannot heal Selma's failing health, which is caused by unhappiness. She begins to see death as her rescuer.

In terms of the intra-textual aspect, the TBW is very rich with word plays. The language in the novel contained various figures of speech or figurative languages (FL) to name a few those which are appearing constantly are metaphor, simile, and personification. Figurative language is a 
variation of language that differs from traditional form. It is used to describe person or object. The novel used figurative language to make the imaginative description becomes almost real. The language is very beautiful because the novel is written in prose poem form meaning that it is a novel which language is in the form of poem.

In the perspective of translation theory, the novel contains many cultural words being said as Lebanese culture. This is a very challenging for translation how she/he will translate and try to find the equivalent of the words and phrases that contain cultural nuances. This review on TC also covers the quality of the translation in TT SSP overall, whether the principles of CAN (clarity, accuracy, and naturalness) have been met or not. Further elaboration is displayed in below analysis:

\begin{tabular}{|c|c|}
\hline ST & TT \\
\hline $\begin{array}{l}\text { I was eighteen years of age when love opened } \\
\text { my eyes with its magic rays and touched my } \\
\text { spirit for the first time with its fiery fingers, } \\
\text { and Selma Karamy was the first woman who } \\
\text { awakened my spirit with her beauty and led } \\
\text { me into the garden of high affection, where } \\
\underline{\text { days pass like dreams and nights like }} \\
\underline{\text { weddings. (TBW:1) }}\end{array}$ & $\begin{array}{l}\text { Usiaku baru menginjak delapan belas tahun saat } \\
\text { cinta membuka kedua mataku dengan pancaran } \\
\text { magisnya dan untuk pertama kalinya } \\
\text { mengguncang jiwaku melalui sentuhan jari- } \\
\text { jarinya yang berapi. Salma Karami adalalah } \\
\text { perempuan pertama yang mampu menggugah } \\
\text { perasaanku dengan kecantikannya serta } \\
\text { membawaku masuk ke dalam tanah kasih yang } \\
\text { agung di mana hari-hari berlalu laksana } \\
\text { mimpi dan malam-malamku layaknya pesta pora } \\
\text { (SSP: } 1)\end{array}$ \\
\hline
\end{tabular}

In the above example, the phrase "garden of high affection" is translated into "tanah kasih yang agung"; this may lead to a different perspective in perceiving the garden which usually symbolizes a place where two lovers spend their romantic encounter. In the western perspective, a garden is portrayed as something beautiful and it is being equalize with the beauty of love whilst in the translation the word "garden" is changed into "tanah kasih" which deviate from the meaning of garden of love. In this sentence, the translator also retains the aspect of FL having simile in the clause "days pass like dream" and "nights like wedding". These expressions of simile are to make a direct comparison between days and dream, days pass in human life is so fast as if they are a mere dream. The "nights" equates with "wedding" this means that at night time the writer feels happy and this should call for a celebration, a celebration that usually happens in a wedding. The translator's effort in translating the expressions resulted in the fulfillment of CAN principles. In terms of the strategy, this translation tries to be as communicative as possible. Communicative translation seeks to bridge meaning between ST and TT.

\begin{tabular}{|c|c|}
\hline ST & $\mathrm{TT}$ \\
\hline $\begin{array}{l}\text { I was deeply engrossed in thought and } \\
\text { contemplation and seeking to understand the } \\
\text { meaning of nature and the revelation of books } \\
\text { and scriptures when I heard LOVE whispered } \\
\text { into my ears through Selma's lips. My life was } \\
\text { a coma, empty like that of Adam's in Paradise, } \\
\text { when I saw Selma standing before me like a } \\
\text { column of light. She was the Eve of my heart } \\
\text { who filled it with secrets and wonders and } \\
\text { made me understand the meaning of life. } \\
\text { (TBW: 1) }\end{array}$ & $\begin{array}{l}\text { Aku begitu asyik, larut dalam bayangan dan } \\
\text { lamunan, mencoba mengerti makna semesta } \\
\text { raya, terlena oleh rahasia kitab-kitab dan Injil, } \\
\text { ketika kau mendengar cinta membisik di } \\
\text { telingaku melalui bibir Salma. Hidupku laksana } \\
\text { terhenti, hampa seperti Adam di sorga, ketika } \\
\text { aku melihat Salma bagaikan Hawa bagi hati } \\
\text { yang penuh dengan rahasia-rahasia dan } \\
\text { keajaiban-keajaiban ini dialah yang } \\
\text { membuatku paham arti kehidupan (TBW: 2) }\end{array}$ \\
\hline
\end{tabular}


This example shows the variety of forms of intra-textual. The figurative language shown in this example is simile which makes direct comparison between the writer's lives that turns into coma as if in Adam's Paradise. The reason why the writer is in the state of coma is to depict the kind of amazement he has on Salma that makes him become frozen and captivated by Salma's beauty. The sentence also compares Salma and Eve. As most people known that Eve is described as Adam's wife who was very beautiful, in this case Salma is as beautiful as Eve. The similes are the kinds of FL mostly exist in Gibran's TBW. Stylistically the most important influence on Gibran's writing was that of the Bible - its straightforward prose; its employment of parables and allegories; its modes of expression. Taking the Bible as his cue, Gibran cultivated what might be termed the "prose poem," modeled on the Psalms of David instead of the traditional qasidah, the polythematic ode of classical Arabic poem. (https://www.encyclopedia.com/arts/culture-magazines/brokenwings, accessed July 12, 2020).

Aside from the recurring existence of similes, this paragraph was translated as accordingly to the CAN principles. It means that no meaning is deviated from the ST. One thing to consider is how in the TT, the writer writes LOVE in all capital letters while in Indonesian it was only translated as "cinta". The intention of Gibran by using capital is not only to emphasize the love but also to make it as if it is a living thing. This may again signal the existence of personification that, "Love whispered into my ears..." Personification is kind of figures of speech that used by giving the attributes of a human being to an animal, an object, or a concept (Abrams, 1999).

\begin{tabular}{|c|c|}
\hline $\mathrm{T}$ & TT \\
\hline $\begin{array}{l}\text { You speak of those years between infancy and } \\
\text { youth as a golden era free from confinement } \\
\text { and cares, but I call those years an era of } \\
\text { silent sorrow which dropped as a seed into my } \\
\text { heart and grew with it and could find no outlet } \\
\text { to the world of Knowledge and wisdom until } \\
\text { love came and opened the heart's doors and } \\
\text { lighted its corners. Love provided me with a } \\
\text { tongue and tears. }\end{array}$ & $\begin{array}{l}\text { Kalian menyebut tahun-tahun antara masa kecil } \\
\text { dan masa muda sebagai masa keemasan yang } \\
\text { terbebas dari aturan dan kungkungan. Namun } \\
\text { bagiku tahun- tahun tersebut adalah sebagai } \\
\text { sebuah masa kedukaan yang bisu, Ia tumbuh } \\
\text { laksana benih di dalam hatiku dan berkembang } \\
\text { pula bersamanya. Tak dapat menembus duania } \\
\text { pengetahuan dan kebijaksanaan hingga cinta } \\
\text { datang dan membuka pintu-pintu hati } \\
\text { serta menyinari pojok-pojoknya. Cinta } \\
\text { menganugerahiku bahasa dan airmata. }\end{array}$ \\
\hline $\begin{array}{l}\text { Every time I close my eyes I see those } \\
\text { valleys full of magic and dignity and those } \\
\text { mountains covered with glory and greatness } \\
\text { trying to reach the sky. }\end{array}$ & $\begin{array}{l}\text { Setiap kali aku berpejam, aku menyaksikan } \\
\text { lembah- lembah penuh keajaiban dan keindahan } \\
\text { serta gunung- gunung yang dikelilingi oleh } \\
\text { keagungan dan kemuliaan yang mencoba } \\
\text { merambah langit ... }\end{array}$ \\
\hline $\begin{array}{l}\text { All those beauties which I speak of now and } \\
\text { which I long to see, as a child longs for his } \\
\text { mother's breast, wounded my spirit, } \\
\text { imprisoned in the darkness of youth, as a } \\
\text { falcon suffers in its cage when it sees a flock } \\
\text { of birds flying freely in the spacious sky. } \\
\text { Those valleys and hills fired my } \\
\text { imagination, but bitter thoughts wove round } \\
\text { my heart a net of hopelessness. (TBW: 2) }\end{array}$ & $\begin{array}{l}\text { Seluruh keindahan yang aku sampaikan } \\
\text { sekarang ini dan aku rindukan ini tak ubahnya } \\
\text { laksana seorang bayi merindukan tetek ibunya, } \\
\text { melukai jiwaku yag terpenjara dalam } \\
\text { kekelabuan masa muda. Semisal seekor elang } \\
\text { menderita sendirian dalam sangkarnya tatkala } \\
\text { melihat sekawanan burung terbang bebas di } \\
\text { langit yang luas. (SSP: } 5-6)\end{array}$ \\
\hline
\end{tabular}


There are three interesting discussion in this paragraph. The style of language contained in it is engulfed with simile, the clause "... which dropped as as seed into my heart and grew with it ..." is translated into "...Ia tumbuh laksana benih di dalam hatiku dan berkembang pula bersamanya." The word "seed" is being used to represent the silent sorrow that the writer felt. The seed can grow into tree, and it goes with the feeling of sorrow that will always remain in the writer's heart and life. This again to show how he is in a very state of deep sorrow, loneliness, and torn apart because the love of his life is returned to the Almighty. He thinks he cannot live without Salma because the love he has for her has given him the strength to speak and to feel sadness. The other two cases of similes are by phrasing "... as a child longs for his mother's breast, as a falcon suffers in its cage..." they were translated into another form of similes "tak ubahnya laksana seorang bayi merindukan tetek ibunya," and "Semisal seekor elang menderita sendirian dalam sangkarnya." The baby needs mother's milk to survive; the falcon cannot be left alone in the cage because the falcon is grand. These two direct comparisons are to signal that the writer is longing for the love. In terms of the quality of the translation, these clauses are clearly, accurately and naturally translated into the form of similes. The translator retains the stylistic, the effect, and the meaning of the words into TT. In conclusion, no deviation of meaning is occurred.

Besides the use of simile in this sample, the text also contains cultural word by showing the condition of landscape in Lebanon. As Newmark (1988) stated that cultural word is "the way of life and its manifestations that are peculiar to a community that uses a particular language as its means of expression", he then adds the category for cultural words are: 1) Ecology: flora, fauna, hills, winds, plains; 2) Material Culture: food, clothes, houses and towns, transport; 3) Social Culture: work and leisure; 4) Organizations Customs, Activities, Procedures; 5) Gestures and habits. The description of "....... Valleys full of magic and dignity and those mountains covered with glory and greatness trying to reach the sky." The cultural word in this sentence is the valleys and mountains in Lebanon which the writer described so greatly, to show his amazement of their beauty. The mountains and valleys are included into the ecology. He also personified them as if they are living objects trying to reach the sky with their hands, in this case with their peaks.

Overall the translator did amazing translation in terms of retaining the form of prose poem of Gibran, the richness of the word plays, and the effect of the translator towards readers of TT. The communicative strategy of translation is used by the translator. Newmark mentioned the importance of having communicative method as it attempts to render the exact contextual meaning of the original in such a way that both content and language are readily acceptable and comprehensible to the readership (1988).

\begin{tabular}{|c|c|}
\hline ST & TT \\
\hline $\begin{array}{l}\text { In the spring of the wonderful year, I was in } \\
\text { Beirut. The gardens were full of Nisan } \\
\text { flowers and the earth was carpeted with green }\end{array}$ & $\begin{array}{l}\text { Saat musim semi di tahun yang indah itu, aku } \\
\text { berada di Beirut. Taman-taman penuh dengan } \\
\text { bunga-bunga Nisan* dan bumi berhampar }\end{array}$ \\
\hline $\begin{array}{l}\text { grass, and like a secret of earth revealed to } \\
\text { Heaven. The orange trees and apple trees, } \\
\text { looking like houris or brides sent by nature to }\end{array}$ & $\begin{array}{l}\text { rumput hijau, semua seperti rahasia yang } \\
\text { diperlihatkan bumi kepada langit. Pohon-pohon } \\
\text { badam dan apel terlihak laksana mempelai }\end{array}$ \\
\hline inspire poets and excite the imaginatio & pengantin dengan gaun putih bunga-bunga oleh \\
\hline $\begin{array}{l}\text { wearing white garments of perfum } \\
\text { blossoms. (TBW: } 3 \text { ) }\end{array}$ & $\begin{array}{l}\text { alam untuk mengilhami para penyair dan } \\
\text { membangkitkan gairah fantasi. (SSP: 9) }\end{array}$ \\
\hline
\end{tabular}

The above example shows another occurrence of cultural words and figures of speech. "The gardens were full of Nisan flowers...", The phrase "Nisan flowers" in ST is to show the month of April during the spring season where flowers bloom beautifully in Lebanon. It is a month of 
flowers, the first month of the Jewish sacred year. The phrase is translated into "bunga- bunga Nisan" this may not be suitable translation due to having implied meaning that the cultural word "Nisan" might be perceived as the name of the flower though in fact it is referring to the name of month when flowers bloom, it is in spring time. The phrase "The orange trees and apple trees..." is translated into "Pohon-pohon badam dan apel ....", the translate the cultural "orange trees' as "pohon badam" this may lead to inequivalent of translation. In Indonesia, we have orange to refer to "jeruk" instead of 'badam'. The translator seeks to find the exact object to signify fruit that is grown mostly in the region of Lebanon, the Badam trees. "Badam" is a species of tree native to Iran and surrounding countries but widely cultivated. Badam halva is a sweet made from almonds with added coloring. The other case of cultural word is in the word "houris", the meaning is a beautiful young woman, especially one of the virgin companions of the faithful in the Muslim Paradise. In Indonesia we do not have equivalent for the word "houris", we may simply refer them as "virgin". The translator realized this difficulty and evading translating the word. The cultural words in this paragraph are describing the ecology "Nisan" and "houris" is included into organization and customs.

Gibran compares the beautiful sight of orange and apples trees as if they are beautiful woman or bride wearing the wedding gown and perfumed that smells of the flowers. The simile "The orange trees and apple trees, looking like 'houris' or brides sent by nature to inspire poets and excite the imagination, were wearing white garments of perfumed blossom" into "laksana mempelai pengantin dengan gaun putih bunga-bunga oleh alam untuk mengilhami para penyair dan membangkitkan gairah fantasi". To relate the beauty of orange and apple trees and to beautiful bride or woman, Gibran tries to implicate that those beauty will ignite the poet's inspiration in creating masterpiece, to lure the fantasy coming out from the mind of the poet. In terms of reviewing and evaluating the translation in the TT, translator has fulfilled the CAN by providing communicative translation.

Translation criticism can be conducted by employing Nord's theory of extra-textual and intra-textual aspects. This analysis of extra-textual focusing on the ST and TT has shown that the intention of Gibran to write TBW is to depict the life during his era during which the era deals with various problems that plagued early-twentieth-century Lebanon-outworn social conventions, clerical corruption, and the status of women. Gibran appears to be the implacable enemy of outworn social conventions, of clerical and secular corruption, and of feudalism. TBW has defied categorization. It is perhaps most aptly described as a "love-poem-in-prose," unified by the force of its universal theme of love, though critics have regarded it from the traditional perspective of the novella. TBW is translated by Sabri from Yayasan Bentang Budaya. No single information is achieved about Sabri, but Yayasan Bentang Budaya is a famous publisher focuses mostly on translating cultural and literary novels.

Based on the analysis of the intra-textual aspects, it is shown that TBW contains many figures of speech, to name a few are the similes which dominate, the metaphor and the personification. TBW is a kind of prose poem whereby the content is in the form of novel but presented also as poem. The stylistic form of poem in the flow of prose is narrated through first person. Some say TBW is a reflection of Gibran's experience, his longing for love for Hala. When Gibran returned to Lebanon in 1898, this attitude of condescension on the part of the father persisted. But it was the brother, Iskandar, who decided that no marriage between Gibran and his sister Hala would take place. His other sister, Sa'ida, became important to scholars as an informant about this love affair between Gibran and Hala. Apparently when Gibran bade Hala farewell, he gave her a ring, a lock of his hair, a vial (in which there were some drops of his tears), and his cane. Hala never married and died a blind woman in 1955. This personal experience of Gibran is clearly affected the way he wrote TBW, Salma is the representation of Hala. 
TBW also contains so many cultural words that refer to ecology to describe the beautiful landscape of the Lebanon, the material culture to describe the flowers, fruits, and also the organization of Lebanese with the "houris". The translator was able to perceive and retain the meaning of each making the translation fulfilled the criteria of good translation, clear, accurate and natural. In some examples in SSP, the writer indicates the use of the additional strategy to elaborate concept that is unclear and ambiguous to the readers of TT.

\section{CONCLUSION}

The emerging concept of Translation Criticism (TC) has been flourishing during recent years yet not really in favor by so many people. This concept allows people to distinguish the bad from the good translation; overall it looks on the overall aspects of translation. Not until recent years that this area in translation study has long been neglected due to the difficulty in achieving appropriate evaluation or we say as criticism. The purpose of TC is not to determine whether a translation is "correct" or "incorrect" or "bad" or "good" rather to analyze what sort of decisions are taken into account during translation process. Then, as the translation study went under development, many approaches emerged one of it is error analysis which then became the embryo of TC. TC is no longer conveying subjectivity rather more to the systematic analysis on the product of translation. The criticism should be taken into account the other aspects of analysis, evaluation, interpretation, and or assessment in translation. The critics should also consider the text type as stated by Reiss (2000) into: informative texts, expressive texts, operative texts and audio-medial texts. A critic should be able to understand the nature of the text types before he/she conducting critique and the linguistics components of the texts such as phonology, morphology, semantics, syntax, and discourse.

In conducting TC, text analysis is really pertinent. It is considered as the foundation to be able to conduct TC. By analyzing the texts of ST and TT, the critic can determine what solutions the translators have to offer when they come across problems in translating. The importance of text analysis in conducting TC is posed by Nord (2005); he stated that extra-textual and intra- textual factors are really important. Extra-textual factors are communicative and situational factors that use ST. These factors constitute a text's external structure, and they include the Sender, Sender's intention, audience, medium/channel, place, time, motive, and function (Nord 2005). The intratextual factors are those factors concerned mostly with the internal factors of the translated text including: subject matter, content, and composition of the text, presuppositions, lexis, sentence structure, and even non-verbal elements.

The analysis of extra-textual focusing on the ST and TT has shown that the intention of Gibran to write TBW is to depict the life during his era during which the era deals with various problems that plagued early-twentieth-century Lebanon. It is perhaps most aptly described as a "love-poem-in-prose," unified by the force of its universal theme of love, though critics have regarded it from the traditional perspective of the novella. Based on the analysis of the intra- textual aspects, it is shown that TBW contains many figures of speech, to name a few are the similes which dominate, the metaphor and the personification. TBW also contains so many cultural words that refer to ecology to describe the beautiful landscape of the Lebanon, the material culture to describe the flowers, fruits, and also the organization of Lebanese with the "houris". The translator was able to perceive and retain the meaning of each making the translation fulfilled the criteria of good translation, clear, accurate and natural.

\section{REFERENCES}

Abrams, M. H. 1999. A Glossary of Literary Terms/ Seventh Edition.USA: Heinle\&Heinle Buhler, K., Goodwin, D. F., \& Eschbach, A 1990. Theory of Language: The Representational 
Function of Language. John Benjamins Publishing Company, Amsterdam.

Hatim, B., \& Mason, I. 1997. The Translator As Communicator. Oxon: Routledge.

Hewson, Lance ETI, University of Geneva. An Approach to Translation Criticism Emma and Madame Bovary in translation. [Benjamins Translation Library, 95] 2011. ix, 282 pp.status: Available@ John Benjamins Publishing Company.https://doi.org/10.1075/btl.95

Kreiner, Cecilie. Perspectives Journal: Studies in Translation Theory and Practice. Volume 13, 2006 - Issue 4ious studies: Translation Criticism and Unknown Source Texts. Pages 278-288 Published online: 05 Jan 2009. Download citation https://doi.org/10.1080/09076760608668998

Larson, M. L. 1984. Meaning-Based Translation: A Guide To Cross-Language Equivalence.

Lanham dan London: University Press of America.

Munday, J. 2012. Translation Evaluation: Critical Points of Translator Decisionmaking. London: Routledge.

Newmark, P. 1988. A Textbook of Translation. New York: Prentice Hall. 